\title{
What's in a Place?
}

The Contribution of

Strategic Communication to

Placemaking and Territorial

Communication

https://doi.org/10.21814/uminho.ed.46.16

\section{Ana Duarte Melo}

Communication and Society Research Centre, Institute of Social Sciences, University of Minho, Braga, Portugal

https://orcid.org/0000-0002-4598-7174 



\section{Abstract}

Set in the field of territorial communication, the aim of this chapter is to summon the various contributions of strategic communication to placemaking and promotion, approaching them both through a mind frame path, as a multi-layered concept, and through an operational approach, as a pragmatic tool. Going through a number of examples we will reflect on several experiences to illustrate the potential of strategic communication to add value to places in different sets and scales, from building a place almost from scratch to nation branding strategies, from positioning and re-positioning objectives to building up notoriety or developing communities' sense of belonging to a territory. We also set an evolutionary frame of the territorial communication in the light of its strategic dimension, drawing on key concepts and trends, influences and achievements. The performative value of strategic communication as a constructive tool of territorial development is discussed in addition to the communicational added value of territorial brands, namely by pointing emerging issues such as storytelling or participatory place communication. Furthermore, we summon ethical and pragmatic challenges to the debate as inspiration for future research.

\section{Keywords}

territorial strategic communication, placemaking, place branding, place storytelling, participatory communication, communication for sustainable development

\section{What's in a Place?}

My place is not your place. (Zenker \& Beckmann, 2013, p. 6)

What a place is and how it is built based on strategic communication is the question that any territorial decision maker, planner, manager, practitioner, stakeholder or student should ask to begin to reflect on this theme, so complex and involving. Answers should be diverse, according to different perspectives, perceptions, and expectations. And all of them could be relevant, meaningful, and legitimate.

This multi-layered approach to territorial reality results in a conceptual-pragmatic conundrum. This emerges already from the definition of place, or landscape, or territory, according to different fields of knowledge, from 
geography to politics, from ecology to law or communication (Bueno, 2004; Champollion, 2006; Domingues, 2001).

Territory and space are not equivalent notions. The territory with precise contours and limits is a historical construction, the product of human action. A seemingly universal, falsely natural category, the territory is anything but spontaneous. Beyond the natural borders, the political border is always an abstract line and agreed upon by some. (Bueno, 2004, p. 229)

More recently, other authors consider 'place' is conceived as a service system and in building competitive identity to obtain reputation through value co-creation processes" (Bassano et al., 2019, p. 11).

The marketing perspective (Kotler et al., 1999; Kotler \& Gertner, 2002), on the other hand, indicates a business-driven approach to the idea of place:

nation state, a geopolitical physical space; a region or state; a cultural, historical or ethic bounded location; a central city and its surrounding populations; a market with various definable attributes; an industry's home base and a clustering of like industries and their supplier; a psychological attribute of relations between people internally and their external view of those outside. (Kotler, 2002, p. 4)

This point of view is highly embedded with a corporation management insight translated to territories, emerging from the observation of declining cities or "places in trouble":

there is now a consensus about the suitability of marketing for places, and that places, indeed, should be marketed as efficiently as firm's market products or services ( ...) every community has to transform itself into a seller of goods and services, a proactive marketer of its products and its place value. Places are, indeed, products, whose identities and values must be designed and marketed. Places that fail to market themselves successfully face the risk of economic stagnation and decline. (Rein et al., 1993, p. 10)

But even the father of marketing recognizes that "unlike purely business or commercial product marketing, place marketing requires the active support of public and private agencies, interest groups, and citizens" (Rein et al., 1993, p. 20). 
The need for a shared vision and a shared meaning is also central in the operational performance of the notion of territory in communication.

The great challenge here will certainly be to find an identity and a vision of meaning shared by all. This is a continuous and repeated competition, the struggle for positioning, a founding concept of marketing (Ries \& Trout, 2003) also very relevant in territorial marketing and often the object of its communication strategies, as it is here, in these symbolic borders, that negotiation and legitimization of contemporary territories are at stake. (Melo, 2019b, p. 245)

Despite the viewpoints' diversity there is a general consensus on the idea of "territory" being a human, organisational, social, and cultural construct, involving both spatial and symbolic dimensions and even an existential one, since the territories are lived upon and experienced (Govers \& Go, 2016).

\section{The Convergence of Territory and Communication}

From a communication perspective, territory might be approached as an organization and a network of places, institutions, and stakeholders that need to be taken into account both as content (the place identity, culture, and personality) and as publics and channels in the communication process.

Bassano et al. (2019) use a system design approach to preconize the need to establish communication systems, as well as collaborative socioeconomic ones, to strengthening the competitiveness of a place through smart multilevel governance. By connecting the dots of several settled places through a smart local service system, territorial chaos is transformed in territorial cosmos with and added value. Not only will it "provide the structural conditions for the definition and sharing of a value proposition (place identity and location branding) that is recognizable and consistent with the internal local characteristics and externally aligned with the expectations of stakeholders" (Bassano et al., 2019, p. 13), but it will also promote the systematic engagement of stakeholders in the definition and in the co-creation of the system itself, in a consonance logic to provide a solid proposition.

The meeting between territory and communication emerges from the need to identify, classify, categorize, and even name places. To communicate a place, it is necessary to recognise it as an entity and attribute it an identity. Cartography or geolocation, photography or travel literature, tourist promotion or territorial development projects exert in practise the need to 
communicate a place, representing it - and interpreting it (Bassano et al., 2019) - through more or less complex or semiotically rich communication symbols or codes. Hence, to a certain extent, as a communication insight, one could argue that a place is a territory that needs to be communicated. A place is a territory that becomes meaningful through communication. Therefore, territories are permanently under construction; they are built upon and through communication; communication makes places, whether by branding, promotion or public diplomacy action.

Notwithstanding, placemaking involves more than communication, it results from the contributions and interactions of territorial management and territorial communication.

There are several concepts and expressions frequently used to refer to territorial communication: place branding, territorial marketing, city branding, destination promotion. They are the visible encounter between territorial management and the communication of those territories.

Nevertheless, as words can become meaningless if used indistinctly to convey similar but different meanings, and the interaction between territorial strategic communication and place branding or marketing is probably one of the most illustrative examples, it is important to engage into further definition.

Communication is not (only) marketing. Territorial strategic communication is not territorial marketing or place branding. It is one of the tools that practitioners - territorial governors and managers, territorial marketing strategists and planners, managers of natural parks or territorial networks, mayors, presidents of parish councils, community leaders -, have at their disposal. Therefore, integrated strategic communication must always be guided by a more comprehensive strategic axis, frequently emerging from territorial management that, in turn, has in marketing one, only one, of multiple tools and components.

This particular idiosyncrasy places territorial communication in a permanent state of dependence on a set of circumstances, decisions and measures that are prior to it. And this is one of the biggest challenges of territorial communication: consistently responding to communication challenges despite of imposed constraints. This immediately implies demystifying a common assumption: communication aims to solve communication problems, not territorial problems, which in turn implies a correct and relevant 
definition of communication strategy problems and objectives within the territorial management scope.

As much as this observation may sound as a disclaimer, we find it relevant. The process of questioning and reflecting on the what a place is, means or dreams to become - small "cities should be seen in terms not just of what they have, but also of what they can become" (Richards \& Duif, 2019, pp. 24-25) - should be prior to the definition of a territorial strategic communication problem and to the design of the respective strategy to find a solution, but frequently the whole process only begins when the thinking about communication starts.

This happens for a number of reasons, namely the overrating of communication as panacea for territorial management problems. But looking at communication as a tactical, rapid, and spectacular response to a strategic structural problem in a territory will necessarily result in a superficial and frustrating response in the long term. Therefore, there is a need for an integrated strategic mindset to tackle territories and, subsequently, territorial communication set to stimulate, develop, and integrate different territorial dimensions, in a quest for co-intelligent (Atlee, 2017) and smart territories (Giovannella, 2014).

On the other hand, the process of thinking a territory from a communication perspective often entails participatory (Melo, 2019b) and reflective approaches that contribute to the co-creation of meaning, consensus building and negotiation, stakeholders' engagement, and the strengthening of the community' sense of place.

\section{Theoretical Approaches and Models}

Perspectives on territorial communication mirror the complexity of this field, deriving from concepts and approaches as diverse as the ones the definition of territory can entail (Fan, 2006). And they also may vary according to the dimension and type of territory - nation branding, city branding or networked territories grouped by specific criteria (geographic localization or cultural identity, for example) - as well as according to its use destination branding, tourist promotion, residential quality of living (Insh, 2013), population increase or investment attraction (Middleton, 2011) most certainly should be approached differently and should result in diverse communication strategies. 
As strategic communication is focused on solving communication problems or on strategically using communication opportunities, territorial communication must adapt its potential to its specific needs. But how does it build its founding concepts and its functional tools?

For operational purposes we would consider the contributions of several communication conceptual universes to territorial strategic communication, namely, organizational, political, and marketing communication. All of them contribute to the construction of meaning of territories and therefore semiotic, rhetoric, persuasion, and critical discourse are interwoven in all possible approaches as transversal and powerful communication tools.

The approach of territories as organizations, embedding a structural communicative system that integrates the territory itself in a constitutive and organic way, according to the communicative constitution of organizations theory (McPhee \& Zaug, 2009; Putnam \& Nicotera, 2009; Taylor, 2009). It entails internal and external communication, formal and informal communication, communication fluxes and a network of constant interactions that compare with the nervous system of living bodies. At the corporation management level, communication is also recognized as a management dimension and as a tool which matches perfectly the performative output of territorial communication.

The political communication approach deals with the territory as an entity of power and inherits the long tradition of public diplomacy in a constant competition for political supremacy, resources, and reputation in the geopolitical arena, involving permanent processes of repositioning and negotiations in which communication proves to be crucial (Dolea, 2015, 2018; Gilboa, 2015; Ingenhoff et al., 2018).

And the marketing approach tackles the territory as a mix of product, service, and experience to be consumed, used, and lived by the respective target, public or stakeholder. The communication role within this perspective is frequently how to make the territory tangible, recognised and desirable.

Branding is the visible encounter between territorial management and territorial marketing, thus territorial communication. Therefore, we would consider place branding and promotion a relevant field of work to assess the contributes of strategic communication to the management and development of territories. 
"In its interaction with the territory, strategic communication plays a role in promoting, building brand, image and reputation where it constantly reinvents itself" (Kavaratzis \& Kalandides, 2015, p. 1369). Present across all levels of city marketing (Azevedo, 2017), for example, "communication adds immaterial value to the territory, materialized in its attractiveness, as a driver of notoriety, action and the desire to visit, invest or reside" (Melo, 2019b, p. 245).

Since the 70 s a series of models have been developed with the intention of tackling territorial branding and communication. Although the basics of branding (Aaker, 1996) apply to territories, some specificities have been found and developed, centred on different components of a territorial brand. Their relevance varies with the purpose of their use, whether they have a marketing promotion emphasis as tourist destination branding, for example, or a more managerial or strategic mind frame, as repositioning a territory in the mind of political decision makers, residents or investors.

Pobirchenko et al. (2019) list a number of territorial branding models, highlighting for instance the strategic territorial brand management model (Hanna \& Rowley, 2013, 2015). Hanna and Rowley (2015), developed an integration attempt of existing models, directed to practitioners, taking into account tangible (e.g., infrastructures, landscape) and intangible (e.g., services, infrastructure) territorial features that result into functional and experienced attributes. They also focus on the construction of the brand taking into account the relationship between leadership and stakeholders and the need to a permanent assessment of the brand, articulating the brand architecture and identity with the brand communication in order to achieve a desired brand perception (Hanna \& Rowley, 2013).

The territorial brand as an expression of a country's competitive identity (Anholt, 2007, 2012) is set in the classic Anholt's hexagon model (Anholt 2010), considering six structural features:

1.domestic and foreign policy;

2.business and investment;

3. export brands;

4.culture and heritage; 


\section{5.tourism;}

6. people.

Other models built on a relational network perspective (Hankinson, 2004, 2015). Graham Hankinson (2004) developed a tourist destination brand model centred on the brand's core (personality, positioning, and reality) and developed through four relationships axes: infrastructures, services, consumers, and media. Communication wise this model is quite specific: on media relationships the author distinguishes between organic communications and induced or marketing communication, including publicity, public relations, and advertising (Hankinson, 2004).

Territorial image is the frame of Kavaratzis' model (Kavaratzis, 2005) as well as the 4D model of the country image (Buhmann \& Ingenhoff, 2015) that is frequently applied on comparative studies.

\section{Trends and Inspirations}

From themed park territories to authentic cultural identity rescue examples, the achievements of territorial communication (and its failures) are as multiple and diverse as one can imagine. Over the years strategic communication applied to the territory has been following trends in other areas of communication, namely, organizational or tourism communication; shifting towards a more integrated (Buhmann \& Ingenhoff, 2015) and critical perspective of communication: "it is time to go beyond the prescription of "how to' promote the country, to address instead the hard 'why' questions, thus problematizing and contextualizing the phenomenon, its implications and, above all, its impact at social level" (Dolea, 2015, p. 275). Current trends in territorial communication embed a multidirectional and multiplatform mix, less imposing and more involving, more dynamic, and more participatory communication (Kavaratzis, 2017; Kavaratzis, \& Kalandides, 2015).

\section{The Less Walked Track}

Small is meaningful, exotic is attractive, thus they have a communicative power. Revisiting small or unknown places and putting strategic communication attention to them seems to be a trend (Hendrychová, 2015; Kotkin, 2012; Richards \& Duif, 2019) driven both by worn out subjects and models and by emerging possibilities (Bell, 2017), such as a focus on the creative and circular economy or on smart cities (Melo, 2019a). Moreover, 
a consistent wave of "back to basics" trending lifestyles, a shift on the definitions of quality of living and an overall quest for authenticity and reconnection through community building and territorial co-intelligence (Melo, 2019b) helps to build the right setting.

The challenge is, again, to distillate creatively the differentiating traces of territories, and keep them that way in the longer term, after the campaign, action or communication program is over.

\section{Storytelling and the Search for Territorial Consonance}

Storytelling is a powerful territorial strategic communication tool. Defined as intrinsically human, it performs as a way to make sense of a place. Whether through origin myths or through experiential narratives, storytelling is used to provide shared meaning, to fuel coherence and unity to a territory.

Territorial consonance can be observed from the internal and external point of view. The harmony/consonance between the internal components of the system refers to the ability to share resources to achieve the common goal of sustainable and participatory development. This potential depends on the structural compatibility between the components of equipment (which already exist) and systemic components (which can be attracted and connected to the local system), or from collaborative participation. The latter characterizes the external consonance with indigenous systems and it is not necessarily derived from structural compatibility of the territorial system with the expectations and needs of stakeholders (investors, funders, users, etc.). In this perspective, the consonance ensures a shared understanding of the context, which is an essential prerequisite for realizing synergy of relational vocation and identity. (Bassano et al., 2019, pp.12-13)

Strategic communication wise, storytelling is also a reflexive activity with an impact on territories. White et al. (2018) refer to self-representations as a constitutive part of country brands.

In order to produce a story, place stakeholders have to go through an "autobiographic analysis" (Bassano et al., 2019; Bolin \& Ståhlberg, 2015) on what a place is, on how it defines itself in terms of culture and personality, as well as how it wants to be recognized and understood, therefore setting crucial strategic communication axes such as positioning and desired image. 
"Place storytelling enables strategic communication that supports sustainable competitive advantage" (Bassano et al., 2019, p. 10) and it comprises a value co-creation process that needs to follow specifications, namely: a service systems perspectives make storytelling more effective; governance is crucial to manage storytelling if it mediates stakeholder expectations; managing storytelling in a local service system to enhance brand competitiveness (Bassano et al., 2019).

Place stories should be based on unique and distinctive factors conveying the essence of a place to its stakeholders, to strengthen the ties that bind people to the place, to successfully position a place against competitors (Fombrun \& Van Riel, 2003, as cited in Bassano et al., 2019, p. 12).

Furthermore, storytelling is a functional communication tool for territories for it has potential to make communication more appealing and engaging.

People like to tell stories, and people enjoy listening to them even though there may be scepticism surrounding the truth of what is being said. People who live in a place have considerable experience to share with others and through digital media they can be encouraged to share their stories. (Bassano et al., 2019, p. 18)

\section{Participatory Territorial Communication}

Because both visitors, residents, commuters, investors or governors must have an empathic interaction with the territorial brand and with the place' communication strategies, they have to recognize its value and feel involved. Therefore, setting and promoting inclusive communication approaches are in order, from Berlin (Colomb \& Kalandides, 2010) to Bogotá (Kavaratzis \& Kalandides, 2015) or Seoul (Joo \& Seo, 2018).

Stakeholders based branding (Azevedo, 2017; García et al., 2012; Houghton \& Stevens, 2011) is a sign of that trend. Kavaratzis (2012) concludes that there has been a shift on the role of stakeholders in territorial communication and that effective place brands are rooted in their involvement. The interactions dynamics of the mental associations to places has been identified as participatory and co-constructive dimension of place brands (Kavaratzis \& Kalandides, 2015).

Zenker and Erfgen (2014) offer a conceptual approach for place managers to include residents in an operational perspective and Joo and Seo (2018) take 
a step further introducing a "transformative-enhancing' dimension to the existing 'external-internal' city-branding framework" (p. 239) and highlight the political dimension of strategic communication of places as "city branding is no longer solely a neoliberal marketing exercise, but a political project of policy change" (p. 239). In the same line, Kavaratzis (2017) identifies a participatory model with five interrelated stages, that moves away "from the emphasis on 'signs and logos" to develop co-created, "inclusive and participatory type of place brands and a place branding process that considers, embraces, facilitates and encourages interaction and fluidity leading to stakeholder engagement" (Kavaratzis, 2017, p. 102) towards place branding that plays a functional role as a place development tool with pragmatic communication implications:

coordination is necessary $(. .$.$) although frequently lacking. This is$ also crucial because the link between locals and visitors means that all activities (even promotion) are addressing both audiences simultaneously, so separation is neither effective nor desirable. Even if there are activities with a clear orientation towards outsiders, such as an advertising campaign, the locals are the ones who will have to 'enact' and realise whatever promise is made by the campaign. (Kavaratzis, 2017, p. 104)

Advantages of participatory processes of brand building involve direct benefit to stakeholders and a perception of proximity.

The place brand 'comes closer' to the residents because it is not seen as imposed from above (the authorities) or from the outside (some highly paid consultant) but based on the reality of the place as this is lived by the place's residents and experienced by its visitors. This is very important as it leads to the feeling of brand ownership by locals and tourists. A brand developed through the participatory process has significantly higher chances than a traditionally developed brand to be 'owned' by its end users. Locals and visitors are much more likely to share the feeling of ownership and participation. (Kavaratzis, 2017, pp. 104-105)

After all "an effective city brand has to be both intelligible and credible to local people, effectively the owners if not the managers of the brand, who should be engaged at each stage of the branding process" (Houghton \& Stevens, 2011, p. 46). Nevertheless, this may seem a too idealistic proposal 
to practitioners in the field who have to deal with short time decisions, non-inclusive leaderships, political turnarounds, and endless limitations of budget and resources (Hankinson, 2015).

In the same category we could include strategies for community empowerment and for strengthening the sense of belonging to a place. Houghton and Stevens (2011) claim:

there is growing evidence that the most effective city branding initiatives involve and energize a wide range of local players to craft and convey the new message about the place. Equally, there is a weight of evidence that initiatives that do not engage, and in some cases alienate, local stakeholders are almost destined to fail. ( ... ) effective stakeholder engagement is crucial for the acceptance of city branding as an important and respected discipline within urban development and management. The more people are engaged in effective and productive city branding strategies, the more the scepticism and suspicion that surrounds it can be countered. (p. 46)

Ethical implications need also to be addressed - effective participation, representation (Melo, 2019a; Rodkin, 2018) and ownership of territorial brands being some of the issues (Aitken \& Campelo, 2011; Melo, 2019b; Melo \& Balonas, 2019).

In recent years there is a growing shift in research that indicates the preoccupation with the communities that inhabit territories, taking them into consideration in the making of places through communication, whether enhancing the need to engage them in the process - "the failure to engage is particularly problematic given the emphasis that so many areas now place on nurturing local creativity as the source of their new identity" (Houghton \& Stevens, 2011, p. 46) - or identifying it as a key success factor of territorial development:

placemaking has become an important tool for driving urban development that is sensitive to the needs of communities. ( ... ) the development of creative placemaking practices that can help to link small cities to external networks, stimulate collaboration and help them make the most of the opportunities presented by the knowledge economy. (Richards \& Duif, 2019, p. II)

The same authors draw from a series of small cities examples and argue that the adoption of more strategic, holistic placemaking strategies that 
engage all stakeholders can be a more successful alternative than copying bigger places, as it is from the shared resources, expectations and meaning of territories that a relevant vision can emerge:

Small Cities should be seen in terms not just of what they have, but also of what they can become (...) this requires ambition, having a big dream to follow, and also making effective use of the resources that the city can muster on its own, or obtain through partnership and networking. This strategy should be consistent with the DNA of the city, which can give meaning to its programs for locals and outsiders (Richards \& Duif, 2019, pp. 24-25).

Furthermore, community-based ownership and co-creation of place brands proves to be an asset in brand equity. Aitken and Campelo (2011) propose a four R's model - rights, roles, relationships, and responsibilities - to establish ownership and a sense of place with promising outputs: "generating a model that reflects the social ontology of a place ( ...) will lead to authenticity (brand essence), commitment from stakeholders, and brand sustainability in the context of place branding" (Aitken \& Campelo, 2011, p. 930).

\section{Innovative Cases}

Territorial communication is a territorial management tool whose effectiveness is fundamental. In the struggle for differentiation, for the never seen before, innovative strategies can be truly inspiring. We leave here some exemplary cases in which, in one way or another, the creativity and the innovative factor was remarkable.

\section{The Village Where Nothing Ever Happens}

Miravete de la Sierra, "el pueblo en el que nunca pasa nada" (the village where nothing ever happens; Tomás Fuster, 2018), is a paradigmatic case that demonstrates the potential of strategic communication in placemaking.

A curious aspect of this example is that the initial objective had nothing to do with territories or places, but with the need to demonstrate the communicative potential of thematic television channels in promoting a product and reaching audiences. That was the challenge that Shackleton agency took on, starting by looking for an unknown location in Spain, and designing a strategy to make that place well known. The village had only 12 inhabitants and they became the protagonists of the entire campaign 
(and even merchandising figures): "in this way, its twelve inhabitants were converted into objects of worship, to the point that Internet users can buy souvenirs of these 'grandparents' turned into characters. Replicas of the inhabitants are sold" (Miravete de la Sierra, 2021, Section Curiosidades).

The strategy focused on storytelling and integrated communication mix that included four TV spots aired exclusively on thematic cable channels, and a site where visitors could take a digital tour to the village, make reservations, make a donation to the recovery of the old church, and play games related with the lifestyle of the place including the possibility to participate in the supposed "I International Open of Goat Milking". This generated more than 50,000 visits to the site in the first 3 days of the campaign, a wave of publicity, and massive earned media (Cuende Infometrics, 2008).

Since the main objective was to demonstrate the potential of thematic television channels to reach an audience it worked well, but place branding wise, it was more a coincidence or a side effect. Nevertheless, the impact it had in the media, there was an actual impact in the village, that can be observed years after, both in the demographic evolution - from 12 residents in 2008 (Ramirez, 2008) to 31 in 2019 (Miravete de la Sierra, 2021) - and through the user generated content of visitors in the digital world in a never-ending storytelling of the place (Nuria Garcia, 2013), one of the place branding dimensions of the contemporary (Burmann, 2010).

\section{The Swedish Landmark}

Sweden's nation branding has been scoring points for the pioneering initiatives to promote the country and what emerge as core values for the country: democracy, freedom of expression, and a number of typically Sweden stereotypes. Not only the key messages but also the communicational attitude help to build a country image.

Since the case of the Swedish embassy in second life (Bengtsson, 2011), followed by “the world's most democratic Twitter account" (Christensen, 2013), Sweden has been setting a pattern - "heritage of Swedish nation branding initiatives" (Pamment \& Cassinger, 2018, p. 561) - (and expectations) when it comes to bold country branding (Christensen, 2013; Pamment \& Cassinger, 2018).

Transferring the nation communicative drive to common citizens seems to be a democratic practice that entails one of the core values of the brand. 
Sweden is the first country in the world to hand over its official Twitter account to its citizens. Ordinary Swedes are @Sweden one week at a time. Tweet by tweet, the image of Sweden is built: dynamic, innovative and deeply human. No censorship, no limits. (Christensen, 2013, p. 34)

The project "Curators of Sweden", an initiative of the Swedish Institute and Visit Sweden, handed over the country's official Twitter account to citizens, transforming them in communications managers and actors at a time. "As the project website states $(. .$.$) aims to present the country of Sweden$ through the mix of skills, experiences and opinions it actually consists of. By means of the various curators' narrations, not one Sweden is conveyed, but several" (Christensen, 2013, p. 34).

More recently, “The Swedish number”, 2016 (Pamment \& Cassinger, 2018) sets on the idea of freedom of expression, another core value of the brand. Sweden became the first country to have its own phone number, that could be answered by average Swedes (and even the prime minister), who would participate in the action. "Brand Sweden has established a set of national identity resources that may be leveraged through public participation, vast publicity drives via media technologies and through mimicry of the national interest ( ...) nation brands influence identity politics via media technologies" (Pamment \& Cassinger, 2018, p. 561).

Sweden is an example of communicational success, with several efficiency and creative prizes, including Cannes Lions, that comes in line with stereotyping and representational fitting of nation brands. Furthermore, some of the communication actions counterpart previous criticism to nation branding, as "while the brand should speak with the voice of the people, and the people with the voice of the brand, nation branding does not allow for citizens to play a significant role in the branding process" (Widler, 2007, p. 144).

\section{Tactical Opportunity Insights}

Why and when to communicate? Like in many other fields being on the right time in the right place is often the key for success. The next examples highlight the vision of place communication practitioners who saw the opportunity to communicate and managed to take it, even if it emerged from or due to a crisis.

"The best job in the world", 2009, is a classic example of innovation and creativity (Govers, 2015). Set by the Queensland Tourism to boost worldwide 
notoriety to its territory it innovated through the insight, by transforming what could another paradise island destination campaign into an irrefusable job opportunity: Caretaker for the islands of the Great Barrier Reef.

It was rightfully promoted as a job ad in the classified sections and sites, and became an extremely successful communication action: "more than 35,000 applications were received from over 200 countries. The campaign generated more than $\$ 430$ million in estimated global public relations value, with approximately 8.6 million website visits and garnered international news coverage" (Tourism \& Events Queensland, n.d.). Fully prized with several Cannes awards, it ranked "8th on the international list for the world's top 50 PR [public relations] stunts of all time by international PR company, Taylor Herring" (Tourism \& Events Queensland, n.d.).

"Portugal will never leave you - \#Brelcome" is the name of a campaign promoted by Visit Portugal - Turismo de Portugal, the Portuguese tourist authority, in 2019, coinciding with the political moment of the United Kingdom leaving the European Union.

It was an opportunity to reinforce the positioning of Portugal as a destination for the very significant British market - 17\% (Santos, 2019) and part of a tourism contingency plan. With an emotional appeal, starring beautiful views of Portugal, reminding that both countries endure the oldest alliance in the world and playing with the words "brexit" and "welcome", the campaign states: "dear Britons, life is about uncertainty. ( ... ) Brexit may be the word of the day, but from us you will always be hearing Become. Portugal will never leave you" (Visit Portugal, 2019, 00:00:01).

In the Spring of 2020, when the pandemic emergency locked down countries, closed borders throughout Europe, and prevented tourists to travel, the Portuguese tourism authority repositioned its communication to the inner market. In the Summer, emergency measures were alleviated, but the possibility of traveling between countries remained limited. Matching governmental appeals to consumers to boost the local economy and a public eager for freedom after the sanitary lockdown, the campaign "\#TuPodes" (\#YouCan) brought in an insight of privilege and empowerment to the Portuguese: "now that you can, go. ( ... ) go through all that is ours. Visit Portugal" (Visit Portugal, 2020). But the message goes further, highlighting that - unlike anybody else -, they could travel through the "best destination in the world". This is consistent with the fact that the country was voted as the best world destination for 3 years and a candidate for 2020 (Santos, 2020), 
as has been systematically awarded as the "European leading destination" in the last 4 years (World Travel Awards, n.d.).

Both campaigns result from a fruitful partnership between the Portuguese tourist board and the Portuguese creative agency, Partners, that produced already the first $\mathrm{QR}$ code in the typical Portuguese stone sidewalks (Filipe, 2012) and put a $30 \mathrm{~m}$ wave in New York's Times Square to promote Portugal as a unique surf destination and reached to the Creative Cannes Festival (Durães, 2019).

\section{Final Notes}

Strategic communication applied to territories has been evolving in parallel with other trends in communication, from unidirectional top-down to multi-direction horizontal and bottom-up communication, from a structural mindset to a more organic and holistic approach, from a marketing operational tool to a management asset with an inclusive drive.

Throughout the years, different theories, concepts, and models have been established with the aim to solve territorial communication problems and eventually finding solutions to many other afflictions: economic growth, tourism attraction, community integration, ecological behaviour change, citizen driven causes.

Strategic communication has proved to be a powerful tool of territorial management as well as a political, economic and social driver, with contributions from other communication fields such as development, behaviour change, community, and participatory communication as well as marketing, branding, in what could be assumed as the art and techniques of placemaking.

Due to its pragmatic nature and widespread consequences, frequently evaluable only in the long run, territorial strategic communication should be used constructively and consciously. As it frequently deals with communities and with very complex implications, it should always have the public interest in mind. It has proved its potential and efficiency, so it is a powerful an integrative mean to build stronger, more resilient, and more sustainable territories. And, last but not the least, strategic communication application to territories can be a resourceful and motivating driver to discover very powerful territorial visions. 


\section{Acknowledgements}

This work is supported by national funds through FCT - Fundação para a Ciência e a Tecnologia, I.P., under the project UIDB/00736/2020.

\section{References}

Aaker, D. A. (1996). Building strong brands. The Free Press.

Aitken, R., \& Campelo, A. (2011). The four Rs of place branding. Journal of Marketing Management, 27(9-10), 913-933. https://doi.org/10.1080/0267257X.2011.560718

Anholt, S. (2007). Competitive identity - The new brand management for nations, cities and regions. Palgrave Macmillan.

Anholt, S. (2010). Places: Identity, image and reputation. Palgrave Macmillan.

Anholt, S. (2012). Competitive identity. Destination brands. Elsevier.

Atlee, T. (2017). Participatory sustainability: Notes for an emerging field of civilizational engagement. CreateSpace Independent Publishing Platform.

Azevedo, A. (2017). Roteiro para um marketing territorial mais inteligente, criativo, sustentável e inclusivo. In J.Abreu (Ed.), Success full, sasos de sucesso nos municípios portugueses (pp. 21-28). Idioteque.

Bassano, C., Barile, S., Piciocchi, P., Spohrer, J. C., landolo, F., \& Fisk, R. (2019). Storytelling about places: Tourism marketing in the digital age. Cities, 87, 10-20. https://doi.org/10.1016/j. cities.2018.12.025

Bell, P. (2017, July 19). What can big cities learn from small cities? Cities Digest.

Bengtsson, S. (2011). Virtual nation branding: The Swedish embassy in second life. Journal of Virtual Worlds Research, 4(2), 1-26. https://doi.org/10.4101/jvwr.v4i2.2111

Bolin, G., \& Ståhlberg, P. (2015). Mediating the nation-state: Agency and the media in nation-branding campaigns. International Journal of Communication, 9, 3065-3083. https://ijoc. org/index.php/ijoc/article/view/3557

Bueno, B. (2004). Decifrando mapas: Sobre o conceito de "território" e suas vinculações com a cartografia. Anais do Museu Paulista, 12, 193-234. https://doi.org/10.1590/S010147142004000100018

Buhmann, A., \& Ingenhoff, D. (2015). The 4D model of the country image: An integrative approach from the perspective of communication management. International Communication Gazette, 77(1), 102-124. https://doi.org/10.1177/1748048514556986 
Burmann, C. (2010) A call for 'user-generated branding'. Journal of Brand Management, 18, 1-4. https://doi.org/10.1057/bm.2010.30

Champollion, P. (2006, September 19-20). Territory and territorialization: Present state of the caenti thought [Paper presentation]. International Conference of Territorial Intelligence, Alba Iulia, Romania. https://www.researchgate.net/publication/238757898_TERRITORY_AND_TERRITORIALIZATION_PRESENT_STATE_OF_THE_CAENTI_THOUGHT

Christensen, C. (2013). @Sweden: Curating a nation on Twitter. Popular Communication: The International Journal of Media and Culture, 11, 30-46. https://doi.org/10.1080/15405702.2013.751855

Colomb, C., \& Kalandides, A. (2010). The 'be Berlin' campaign: Old wine in new bottles or innovative form of participatory place branding. In G. Ashworth \& M. Kavaratzis (Eds.), Towards effective place brand management: Branding European cities and regions (pp. 173-190). Edward Elgar Publishing.

Cuende Infometrics. (2008, November 25). El caso Miravete - conect - el pueblo en el que nunca pasa nada [Video]. YouTube. https://www.youtube.com/watch?v=xerxPpvGSqc

Dolea, A. (2015). The need for critical thinking in country promotion: Public diplomacy, nation branding, and public relations. In N. Snow, J. L'Etang, J. Heras, \& D. McKie (Eds,), The Routledge handbook of critical public relations (pp. 274-288). Routledge.

Dolea, A. (2018). Public diplomacy as co-constructed discourses of engagement. In K. A. Johnston \& M. Taylor (Eds.), The handbook of communication engagement (pp. 331-345). John Wiley \& Sons.

Domingues, A.(2001).A paisagem revisitada.Finisterra, 36(72), 55-66. https://doi.org/10.18055/ Finis1621

Durães, P. (2019, June 19). Onda gigante da Partners em Time Square chega a shortlist em Cannes. Meios \& Publicidade. https://www.meiosepublicidade.pt/2019/06/onda-gigante-da-partners-time-square-chega-shortlist-cannes/

Fan, Y. (2006). Branding the nation: What is being branded? Journal of Vacation Marketing, 12(1), 5-14. https://doi.org/10.1177/1356766706056633

Filipe, C. (2012, August 24). O primeiro código QR feito em calçada portuguesa. Público. https:// www.publico.pt/2012/08/24/p3/noticia/o-primeiro-codigo-qr-feito-em-calcada-portuguesa-1814295

García, J. A., Gómez, M., \& Molina, A. (2012, June). A destination-branding model: An empirical analysis based on stakeholders. Tourism Management, 33(3), 646-661. https://doi. org/10.1016/j.tourman.2011.07.006

Gilboa, E. (2015). Public diplomacy. In G. Mazzoleni (Ed.), The international encyclopedia of political communication (pp.1-9). Wiley-Blackwell.

Giovannella, C. (2014,June). Smart territory analytics: toward a shared vision [Paper presentation]. SIS - Scientific Meeting 2014, Italy. https://www.researchgate.net/publication/265208551_ Smart_Territory_Analytics_toward_a_shared_vision 
Govers, R. (2015). Rethinking virtual and online place branding. In M. Kavaratzis, G. Warnaby, \& G. Ashworth (Eds.), Rethinking place branding (pp. 73-83). Springer.

Govers, R., \& Go, F. (2016). Place branding: Glocal, virtual and physical identities, constructed, imagined and experienced. Springer.

Hankinson, G. (2004). Relational network brands: Towards a conceptual model of place brands. Journal of Vacation Marketing, 10(2), 109-121. https://doi.org/10.1177/135676670401000202

Hankinson, G. (2015). Rethinking the place branding construct. In M. Kavaratzis, G. Warnaby, \& G. Ashworth (Eds.), Rethinking place branding (pp.13-31). Springer.

Hanna, S., \& Rowley, J. (2013). A practitioner-led strategic place brand management model. Journal of Marketing Management, 29(15/16), 1782-1815. https://doi.org/10.1080/026725 7X.2013.800901

Hanna, S., \& Rowley, J. (2015). Towards a model of the place brand web. Tourism Management, 48,100-112. https://doi.org/10.1016/j.tourman.2014.10.012

Hendrychová, K. (2015, June 29). The future of cities: Think small because small is the new big. Material Times. www.materialtimes.com/en/what-matters/the-future-of-citiesbrthink-small-because-small-is-the-new-big.html

Houghton J. P., \& Stevens, A. (2011). City branding and stakeholder engagement. In K. Dinnie (Ed.), City branding: Theory and cases (pp. 45-53). Palgrave Macmillan.

Ingenhoff, D., White, C., Buhmann, A., \& Kiousis, S. (2018). Bridging disciplinary perspectives of country image reputation, brand, and identity: Reputation, brand, and identity. Routledge.

Insh, A. (2013). Branding of the city as a place attractive for living. In K. Dinnie (Ed.), Branding of territories: World best practices (pp. 21-28). Mann, Ivanov and Ferber.

Joo, Y. M., \& Seo, B. (2018). Transformative city branding for policy change: The case of Seoul's participatory branding. Environment and Planning C: Politics and Space, 36(2), 239-257. https:// doi.org/10.1177/2399654417707526

Kavaratzis, M. (2005). Place branding: A review of trends and conceptual models. The Marketing Review, 5(4), 329-342. https://doi.org/10.1362/146934705775186854

Kavaratzis, M. (2012). From "necessary evil" to necessity: Stakeholders' involvement in place branding. Journal of Place Management and Development, 5(1), 7-19. https://doi. org/10.1108/17538331211209013

Kavaratzis, M. (2017). The participatory place branding process for tourism: Linking visitors and residents through the city brand. In N. Bellini \& C. Pasquinelli (Eds.), Tourism in the city: Towards an integrative agenda on urban tourism (pp. 93-107). Springer.

Kavaratzis, M., \& Kalandides, A. (2015). Rethinking the place brand: The interactive formation of place brands and the role of participatory place branding. Environment and Planning A: Economy and Space, 47(6), 1368-1382. https://doi.org/10.1177/0308518X15594918 
Kotkin, J. (2012, May 8). Small cities are becoming new engine of economic growth. Forbes. https://www.forbes.com/sites/joelkotkin/2012/05/08/small-cities-are-becoming-the-main-engine-of-economic-growth/

Kotler, P. (2002). Marketing places. Simon and Schuster.

Kotler, P., Asplund, C., Rein, I., \& Haider, D. (1999). Marketing places Europe. Pearson Education.

Kotler, P., \& Gertner, D. (2002). Country as brand, product, and beyond: A place marketing and brand management perspective. Journal of Brand Management, 9(45), 249-261. https://doi. org/10.1057/palgrave.bm.2540076

McPhee, R. D., \& Zaug, P. (2009). The communicative constitution of organizations. In L. Putnam \& A. Nicotera (Eds.), Building theories of organization: The constitutive role of communication (pp. 21-48). Routledge.

Melo, A. D. (2019a). City rankings and the citizens: Exposing representational and participatory gaps. In P. Pereira, R. Ribeiro, I. Oliveira, \& P. Novais (Eds.), Society with future: Smart and liveable cities (pp. 154-169). Springer.

Melo, A. D. (2019b). Somos todos "smart"? Co-inteligência, comunicação e sustentabilidade territorial. In J. Abreu (Ed.), Inteligência territorial: Governança, sustentabilidade e transparência (pp. 235-251). Idioteque.

Melo, A. D., \& Balonas, S. (2019). Stickers on politics. The power of a brand is its weakness - a case of activism and subvertising. In I. Ruiz-Mora, G. Gonçalves, \& I. Somerville (Eds.), Organizational and strategic communication research: Global trends (pp. 173-197). LabCom.IFP.

Middleton, A. C. (2011). City branding and inward investment. In K. Dinnie (Ed.), City branding: Theory and cases (pp.15-26). Palgrave Macmillan.

Miravete de la Sierra. (2021, February 26). In Wikipedia. https://es.wikipedia.org/wiki/Miravete_de_la_Sierra

Nuria Garcia. (2013, March 20). Emma en Miravete de la Sierra [Video]. YouTube. https://www. youtube.com/watch? $v=4 t 3 G y e l b 3 S Q \& t=124 \mathrm{~s}$

Pamment, J., \& Cassinger, C. (2018). Nation branding and the social imaginary of participation: An exploratory study of the Swedish Number campaign. European Journal of Cultural Studies, 21(5), 561-574. https://doi.org/10.1177/1367549417751152

Pobirchenko, V., Shutaieva, E., Karlova, A., \& Polyukhovich, E. (2019). Territory brand: Approaches to definition, simulation methodology. Journal of Environmental Management and Tourism, 10(6), 1351-1364. https://doi.org/10.14505//jemt.v10.6(38).18

Putnam, L. L., \& Nicotera, A. M. (2009). Building theories of organization: The constitutive role of communication. Routledge.

Ramirez, C. (2008, September 11). www.elpuebloenelquenuncapasanada.com: Una agencia de comunicación lanza una campaña para promocionar una localidad de 12 habitantes. El País. https://elpais.com/diario/2008/09/12/tendencias/1221170401_850215.html 
Rein, I., Kotler, P., \& Haider, D. (1993). Marketing places: Attracting investment, industry, and tourism to cities, states, and nations. The Free Press.

Richards, G., \& Duif, L. (2019). Small cities with big dreams. Routledge.

Rodkin, P. E. (2018). Place branding: The problem of representation and brand-identification. Service and Tourism: Current Challenges, 12(4), 25-34.

Santos, L. J. (2019, April 12). Brexit? Portugal seduz os turistas britânicos com o \#Brelcome. Público. https://www.publico.pt/2019/04/12/fugas/noticia/brexit-portugal-anda-seduzir-turistas-britanicos-brelcome-1869037

Santos, L. J. (2020, September 30). Portugal volta a ser candidato a "melhor destino do mundo" nos "óscares" do turismo. Público. https://www.publico.pt/2020/09/30/fugas/noticia/portugal-volta-candidato-melhor-destino-mundo-oscares-turismo-1933507

Taylor, J. R. (2009). Organizing from the bottom up. In L. Putnam \& A. Nicotera (Eds.), Building theories of organization: The constitutive role of communication (pp.153-186). Routledge.

Tomás Fuster. (2018, June 18). Miravete de la Sierra Teruel [Video]. YouTube. https://www.youtube.com/watch?v=oh20y2qeucU

Tourism \& Events Queensland. (n.d.). Best job in the world. https://teq.queensland.com/industry-resources/teq-case-studies/best-job-in-the-world

Visit Portugal. (2019, April 18). Portugal will never leave you - \#Brelcome [Video]. YouTube. https:// www.youtube.com/watch?v=hbKDybW8DCl

Visit Portugal. (2020, June 15). Visita Portugal. \#TuPodes [Video]. YouTube. https://www.youtube. com/watch?v=Y7j3cvtWnOE

White, C., Kiousis, S., \& Buhmann, A. (2018). Epilogue: Bridging disciplinary perspectives about country image, reputation, brand, and identity. In D. Ingenhoff, C. White, A. Buhmann, \& S. Kiousis (Eds.), Bridging disciplinary perspectives of country image reputation, brand, and identity (pp. 313-324). Routledge.

Widler, J. (2007). Nation branding: With pride against prejudice. Place Brand Public Diplomacy, 3, 144-150. https://doi.org/10.1057/palgrave.pb.6000055

World Travel Awards. (n.d.). Europe winners day 2020. https://www.worldtravelawards.com/ event/europe-2020

Zenker, S., \& Beckmann, S. C. (2013). My place is not your place: Different place brand knowledge by different target groups. Journal of Place Management and Development, 6(1), 6-17. https:// doi.org/10.1108/17538331311306078

Zenker, S., \& Erfgen, C. (2014). Let them do the work: A participatory place branding approach. Journal of Place Management and Development, 7(3), 225-234. https://doi.org/10.1108/JPMD06-2013-0016 